\title{
KUALITAS PENDIDIKAN BERBASIS FILSAFAT ILMU
}

\author{
Izah Ulya Qadam \\ Universitas Negeri Semarang, Jawa Tengah, Indonesia \\ Izahulya57@gmail.com
}

\begin{abstract}
EDUCATION QUALITY BASED ON SCIENCE PHILOSOPHY. The paradigm of science and religiousintegrityas strengthening the quality of education is a response to the dichotomy of religion and general science. Answering this question can only be solved with the wisdomapproachis not only a man's ability to think critically, systematic, and radical, but also based on the purity of soul that is based on the divine light. The concept of al-hikmah al-muta'aliyyah (bighest wisdom) has raised philosophy to have the highest position since having foundation and clear objectives at once.Through philosophy approach that is neutral and proportional to bridge and simultaneously reconcile these two domains (science and religion). Science and religion are not something separate and not something that one is above the other.The view that religion is higher than science is the influence of the concept about science and religiondichotomy. Science is considered as the creation of human beings that has a relative truth which has a lower position than the religion as God's creation that has the absolute truth.
\end{abstract}

Keyword: Education Quality, Integrity, Religious Studies

\footnotetext{
Abstrak

Paradigma integrasi ilmu dan agama sebagai penguatan kualitas pendidikan merupakan respon terhadap dikotomi keilmuan agama
} 
dan umum. Menjawab persoalan ini hanya dapat dipecabkan dengan pendekatan hikmah (kebijaksanaan) bukan hanya kemampuan manusia berfikir kritis, sistematis, dan radikal saja, namun juga didasari oleh kebersiban jiwa yang didasari cahaya illabi. Konsep alhikmah al-muta'aliyyah (hik-mah tertinggi) telah mengangkat filsafat memiliki posisi tertinggi karena dimilikinya dasar pijakan sekaligus tujuan yang jelas. Melalui pendekatan filsafatlah yang secara netral dan proposional dapat menjembatani sekaligus mempertemukan dua domain ini (ilmu dan agama). Integrasi antara ilmu dan agama. Ilmu dan agama bukan sesuatu yang terpisah dan bukan pula sesuatu yang satu berada diatas yang lain. Pandangan bahwa agama lebih tinggi dari ilmu adalah pengarub dari konsep tentang dikotomi ilmu dan agama. Ilmu dianggap sebagai ciptaan manusia yang memiliki kebenaran relatif yang oleh karenanya memiliki posisi lebih rendah dibanding agama sebagai ciptaan Tuban yang memiliki kebenaran absolut.

Kata Kunci: Kualitas Pendidikan, Integrasi, Ilmu agama

\section{A. Pendahuluan}

Integrasi ilmu dan agama dilihat dari ranah ontologis, epistemologis maupun aksiologis selalu menyisakan persoalan yang tidak pernah tuntas untuk dibicarakan. Berawal dari temuan Copernicus (1473-1543) yang kemudian diperkuat oleh Galileo Galilei (1564-1642) tentang struktur alam semesta yang heliosentris (matahari sebagai pusat tata surya) berhadapan dengan pandangan gereja yang geosentris (bumi sebagai pusat tata surya), telah melahirkan ketegangan antara ilmu dan agama. Penerimaan atas kebenaran ilmu dan agama menjadi satu pilihan yang dilematis. Orang yang menerima kebenaran ilmu akan dianggap kafir karena menolak kebenaran agama, namun apabila menerima kebenaran agama berarti mengingkari kebenaran ilmu.

Di Inggris pada tahun 1870 dalam satu kuliah umum Max Muller telah mengejutkan audiensnya ketika ia mempromosikan apa yang ia disebut sebagai ilmu agama (science of religion). Satu kombinasi yang pada saat itu dianggap aneh karena pasca Origin of Species-nya Darwin, kebenaran ilmu dan agama semakin tidak dapat dipertemukan. Yang satu menyakini bahwa alam semesta terjadi karena ciptaan langsung oleh Tuhan (kreasionisme) dan yang 
lain menganggap alam semesta semata-mata merupakan proses ilmiah yang sangat panjang (evolusionisme). ${ }^{1}$

Dalam esainya yang berjudul The Goal, Einstein mengatakan bahwa ilmu hanya mengetahui dengan pasti pada apa (das sein) yang ada dan bukan apa yang seharusnya (das sollen). Agama menentukan tujuan ilmu dalam makna yang luas, menunjukkan alat-alat untuk mencapai tujuan itu. Bagaimanapun juga ilmu hanya dapat tercipta oleh mereka yang terilhami oleh inspirasi terhadap kebenaran dan pemahaman. Sumber perasaan ini terpancar dari agama. Kondisi ini digambarkan oleh Einstein dengan ungkapan ilmu tanpa agama lumpuh, agama tanpa ilmu buta. ${ }^{2}$

Di dunia Islam dikotomi ilmu dan agama juga muncul meskipun hanya dalam arti difference bukan contradiction sebagaimana di Barat, yaitu manakala Al-Ghazali (1058-1111) membedakan ilmu menjadi dua macam, yaitu ilmu agama yang bersifat wajib dan ilmu umum bersifat sunnah. Karena sifatnya wajib maka kaum muslimin lebih fokus pada pengembangan ilmu agama sehingga -diperkuat dengan berkembangnya tasawufdunia Islam mengalami kemunduran yang luar biasa dalam bidang ilmu. Sementara kalangan muslim juga ada yang meletakkan Islam dalam posisi berlawanan dengan ilmu modern dan menjadi pengkritik tajam atas perkembangan ilmu modern dan hasilhasilnya, lebih jauh bahkan mengharamkan mempelajari ilmu modern dan menggunakan berbagai produknya karena dianggap berasal dari kaum kafir.

Dewasa ini, persoalan hubungan ilmu dan agama lebih mengemukaan dalam ranah etis. Teknologi sebagai anak kandung ilmu dianggap telah menghasilkan dampak negatif bagi kelestarian alam semesta, baik berupa pencemaran lingkungan bencana alam maupun pada kerusakan moralitas manusia. Belum lagi ketika bidang kedokteran menemukan teknologi kloning dan berbagai

${ }^{1}$ Daniel L. Pals, Seven Theories of Religion, terj. Ali Noer Zaman (Yogyakarya: Kalam:, 2001), Hlm. 6.

${ }^{2}$ Max Jammer, Agama Eistein: Teologi dan Fisika (Yogyakarta: Relief-CRCS, 2004), hlm. 48. 
rekayasa genetika yang hendak diterapkan pada manusia. Namun demikian persoalan dalam rabah etis ini tidak berdiri sendiri, karena tentu ada persoalan epistemologi dan ontologi yang berada dibelakangnya.

Di Indonesia, dikotomi ilmu dan agama ini dapat dilihat pada corak pendidikan. Menurut undang-undang yang bertanggung jawab dibidang pendidikan adalah Kementerian Pendidikan Nasional dan Kebudayaan, namun ada Kementerian Agama yang juga mengurus lembaga pendidikan dari tingkat dasar hingga perguruan tinggi. Pendidikan MI/MTs/MA/ STAIN/IAIN/UIN lebih banyak menekankan pada pendidikan agama berbeda dengan SD/SMP/SMA/PT umum yang lebih mengembangkan keilmuan sekuler.

Manajemen pendidikan seperti itu membawa kita kepada apa yang disebut dengan dikotomi penyelenggaraan pendidikan. Kedua lembaga penyelenggaraan pendidikan tersebut semua diakui sah. Keduanya merupakan bagian sistem pendidikan nasional. Ternyata dikotomi tidak saja menyangkut kelembagaannya, akan tetapi pada sisi lain di Indonesia dan bahkan di dunia juga dikenal dua jenis ilmu, yaitu ilmu-ilmu agama dan ilmu-ilmu umum. Keadaannya demikian, diamati sebagai telah terjadi dikotomi dalam memandang ilmu, yang sesungguhnya pandangan tersebut tidaklah tepat. Pihak-pihak yang berkompeten, terutama dari kalangan STAIN/IAIN/UIN pada umumnya tidak sepakat melihat terjadinya dikotomi dalam memandang ilmu tersebut. Dalam berbagai diskusi atau seminar yang membicarakan tentang lembaga pendidikan dan juga ilmu terbelah ini, muncul pikiran-pikiran agar cara pandang ilmu yang dikotomi itu supaya segera diakhiri. Ilmu, kata mereka adalah satu akan tetapi pada kenyataannya secara operasional tidak mudah menyatukan kedua jenis ilmu tersebut. Buktinya, termasuk yang tidak menyetujui terjadinya dikotomi dalam memandang ilmu ini pun, secara terang-terangan masih juga memisahkan antara ilmu-ilmu agama dari ilmu-ilmu umum.Akhir-akhir ini, kehadiran 
kampus Islam seperti Universitas Islam Negeri dibeberapa kota yakni di Jakarta (UIN Syarif Hidayatullah), di Yogyakarta (UIN Sunan Kalijaga), di Malang (UIN Maulana Malik Ibrahim), di Bandung (UIN Sunan Gunung Djati), dan di Makassar (UIN Alaudin) salah satu misinya adalah berupaya mengembangkan keilmuan yang bersifat integratif ini. Namun kenyataannya di masing-masing UIN tersebut selain mengembangkan fakultas agama juga mengembangkan fakultas-fakultas umum. Akibatnya, ilmu-ilmu agama dan ilmu-ilmu umum lagi-lagi masih terlihat dengan jelas terpisah, yakni masih memelihara pandangan dan perlakuan dikotomi terhadap ilmu. ${ }^{3}$

Dikotonomi ilmu pengetahuan antara ilmu agama dan ilmu pengetahuan dikategorikan seperti ini. Ilmu-ilmu ushuluddin, ilmu syari'ah, ilmu tarbiyah, ilmu dakwah, dan ilmu adab dimasukkan dalam kategori ilmu agama, sedangkan ilmu-ilmu alam, ilmu sosial dan ilmu-ilmu humaniora masuk pada kategori ilmu umum. Ilmu agama dikembangkan bersumber pada al-Qur'an dan hadits Nabi, sedangkan ilmu-ilmu umum dikembangkan berdasarkan hasil-hasil observasi, eksperimen, dan penalaran logis.

Tulisan ini berusaha menjawab tentang hubungan llmu dan agama sebagai penguatan kualitas pendidikan melalui pendekatan filosofis, karena filsafatlah yang secara netral dan proposional dapat menjembatani sekaligus mempertemukan dua domain ini.

\section{B. Pembahasan}

\section{Hubungan Ilmu dan Agama}

Ilmu merupakan istilah yang memiliki beragama makna. Menurut The Liang Gie ${ }^{4}$ ilmu dapat dibedakan menurut cakupannya. Pertama, ilmu merupakan sebuah istilah umum untuk menyebutkan segenap pengetahuan ilmiah yang dipandang

${ }^{3}$ Nn. 4 Tabun Universitas Islam Negeri (UIN) Malang (Malang: UIN Press, 2009), hlm. 53.

${ }^{4}$ The Liang Gie, Pengantar Filsafat Ilmu (Yogyakarta: Yayasan Studi Ilmu dan Teknologi, 1987), hlm. 25. 
sebagai satu kebulatan. Dalam arti yang pertama ini ilmu mengacu pada ilmu seumum-umumnya. Adapaun dalam arti yang kedua ilmu menunjuk pada masing-masing bidang bidang pengetahuan ilmiah yang mempelajari satu pokok soal tertentu misalnya antropologi, geografi, sosiologi.

Ilmu dapat pula dibedakan berdasar maknanya, yaitu pengetahuan, aktivitas dan metode. ${ }^{5}$ Dalam arti pengetahuan, dikatakan bahwa ilmu adalah sesuatu kumpulan yang sistematis dari pengetahuan (any systematic body of knowledge). John G. Kemeny menggunakan istilah ilmu dalam arti semua pengetahuan yang dihimpun dengan perantara metode ilmiah (all knowledge collected by means of the scientific method).

Ilmu dikategorikan sebagai pengetahuan yang ilmiah dan dikembangkan melalui metode ilmiah. Menurut Wan Daud, ${ }^{6}$ diteliti dari aspek linguistiknya saja, kata 'ilm memang bermakna luas. Merujuk pada kamus arabic-english lexicon, wan daud menjelaskan, kata 'ilm berasal dari kata 'ain lam mim yang diambil dari kata 'alamah, yaitu tanda, petunjuk, atau indikasi yang dengannya sesuatu atau seseorang dikenal, kognisi atau label, ciriciri, indikasi, dan tanda-tanda. Disebabkan hal seperti inilah, sejak dahulu umat Islam menganggap ilmu berarti al-Qur'an, Syari'at, Sunnah, Islam, Iman, Ilmu Spiritual, Hikmah, dan Ma'rifat -yang semuanya menghimpun semua hakikat ilmu.

Al-Attas ${ }^{7}$ menjelaskan bahwa ilmu merupakan sesuatu yang tidak terbatas (limitless) dan karenanya tidak memiliki ciriciri spesifik dan perbedaan khusus yang bisa didefinisikan. Ia menjelaskan lagi bahwa pemahaman mengenai istilah ilmu selalu diukur oleh pengetahuan seseorang mengenai ilmu dan oleh sesuatu yang jelas baginya. Ketika medan ilmu pada faktanya sangatlah luas, maka pengetahuan seseorang terhadapnya sangat

${ }^{5}$ Ibid., hlm. 26-29.

${ }^{6}$ Wan Mohd. Nor Wan Daud, The Concept of Knowledge in Islam and Its Implication For Education in Developing Country, terj. Munir, Konsep Pengetabuan dalam Islam (Bandung: Pustaka, 1997), hlm. 65.

${ }^{7}$ Ibid., hlm. 104 
terbatas. Oleh karena itu, pasti pemahaman ilmu dari masingmasing orang akan terbatas.

Uraian diatas mengidentifikasikan dengan jelas bahwa ilmu merupakan istilah dalam pengetahuan ilmiah yang tiada batas waktu untuk dikembangkan, diteliti untuk membuktikan suatu kebenaran yang sifatnya tidak mengikat dan obyektif.

Berbicara tentang agama akan lain berbeda dengan ilmu. Dalam Musyawarah Antar Agama di Jakarta tanggal 30 November 1967, terkait dengan agama H.M. Rasjidi mengatakan bahwa agama adalah hal yang disebut sebagai problem of ultimate concern, oleh karenanya tidak mudah untuk didefinisikan. ${ }^{8}$ Mukti Ali menunjukkan tiga alasan mengapa agama sulit didefinisikan, yaitu pertama, pengalaman keagamaan bersifat batiniah dan subyektif. Kedua, membahas arti agama selalu melibatkan emosi. Ketiga, arti agama dipengaruhi oleh tujuan orang yang memberikan pengertian agama tersebut. ${ }^{9}$

Dalam wacana filsafat perensial, agama memiliki dimensi eksoterik (bentuk) dan esotorik (subtansi). Secara eksoterik di dunia ini dikenal banyak agama, namun diantara keragaman agama tersebut setiap agama memiliki substansi yang menjadi titik temu bagi keragaman tersebut. Agama yang dimaksud dalam hal ini adalah agama Islam, namun secara esoterik tentu Islam memiliki nilai-nilai universal yang juga ada di setiap agama. ${ }^{10}$

Dalam wacana pemikiran Islam banyak kalangan memandang tidak ada persoalan antara ilmu dan agama. Pengakuan tentang ayat kauniyah (ayat yang ada dalam alam semesta) dan ayat qauliyah (ayat-ayat dalam kitab suci) telah dipandang cukup untuk menjelaskan bahwa tidak ada pertentangan antara ilmu dan agama dalam Islam, karena secara ontologi kedua ayat tersebut

${ }^{8}$ Endang Saifuddin Anshari, Ilmu Filsafat dan Agama (Surabaya: Bina Ilmu, 1987), hlm. 17.

9 Mukti Ali, Agama, Universitas dan Pembangunan, (Bandung: IKIP, 1971), hlm. 7 .

${ }^{10}$ Aqom Kuswanjono, Integrasi Imu dan Agama Perspektif Filsafat Mulla Sadra, Badan Penerbitan Filsafat UGM: Yogyakarta, 2010, Hal. 35 
berasal dari Yang satu. Turunnya ayat pertama dalam Islam juga dimulai dengan ayat yang "scientific" yaitu (iqra), sejalan pula dengan misi Nabi Muhammad SAW, untuk membahas kebodohan (jahiliyyah), sebagai lawan dari berfikir yang rasioal. Pandangan ini juga diperkuat dengan tersebarnya dalam al-Qur'an ayat-ayat yang berisi perintah bagi setiap muslim untuk selalu berfikir dan mengembangkan ilmu, serta diberikannya derajat yang tinggi bagi orang yang beriman dan berilmu. Dan Islam, menuntut ilmu merupakan satu pencarian religius. ${ }^{11}$ Hadits Nabi SAW yang menyatakan "Tuntutlab ilmu sampai ke Negeri Cina", juga menunjukkan bahwa menuntut ilmu tidak hanya ditunjukan pada ilmu agama. Ungkapan 'Negeri Cina' dalam hadits tersebut tentu dapat dipahami bahwa Cina bukanlah tempat yang tepat untuk mempelajari ajaran Islam.

Ilmu dan agama meskipun dianggap tidak ada persoalan, namun sejarah mencatat keduanya keduanya mengalami pendikotomi, terutama ketika Al-Ghazali memisahkan antara ilmu agama sebagai ilmu ilmu wajib dan ilmu-ilmu umum sebagai ilmu sunnah. Demikian pula berkembangnya tasawuf yang memalingkan umat Islam pada kesalehan individu dengan meninggalkan persoalan keduniawian. Di Indonesia, selama bertahun-tahun dikotomi tersebut terlihat pada pemilihan bidang kajian, yaitu keagamaan yang dikembangkan di Perguruan Tinggi Agama seperti STAIN/IAIN/UIN, adapun keilmuan umum dikembangkan di Perguruan Tinggi Umum.

Ernest Renan secara tegas mengatakan bahwa Islam meskipun secara ontologis menganggap tidak ada masalah antara ilmu dan agama, namun Islam bermasalah dengan ilmu modern. Dalam ceramahnya di Sorbonne pada tahun 1883 yang diberi judul L 'Islamisme et la science, ia menunjukkkan irrasionalitas dan ketidak mampuan masyarakat muslim melahirkan ilmu. Islam

${ }^{11}$ Mehdi Golshani, Issue In Islam and Science, (Tehraniran: IHCN, 1994), hlm. 7 . 
memang pernah meletakkan dasar-dasar perkembangan keilmuan, namun ilmu modern tidak lahir dari rahim kaum muslimin. ${ }^{12}$

Pandangan ini mendapat komentar balik dari Jamal Al-Din Afghani bahwa tidak mungkin terjadi benturan ilmu dan agama, baik tradisional maupun modern, dan ilmu Barat modern tidak lain dari ilmu Islam asli yang dikirim kembali melalui Renaissans dan pencerahan ke Dunia Islam. Pada dasarnya tidak ada yang salah dalam ilmu modern, akan tetapi tafsiran materialistik atas ilmulah yang menjadi inti kontroversi agama dan ilmu. ${ }^{13}$

Pandangan Ernest Renan sebagaimana tersebut diatas tentu tidak memiliki dasar kuat yang didukung oleh fakta sejarah. Uraian berikut akan memberikan gambaran bagaimana kemajuan ilmu telah dicapai di dunia Islam, bagaimana Islam telah memberikan kontribusi pada perkembangan keilmuan bararat, sekaligus membuktikan kesalahan pandangan Renan akan ketidak mampuan masyarakat muslim melahirkan ilmu. Berikut beberapa ilmuan muslim yang telah mewarnai perkembangan keilmuan modern: ${ }^{14}$

a. Ilmuan kimia; Jabir Ibnu Hayyan (latin: Geber) dan Ar-Razi (nama latinnya Razhes).

b. Ilmuan fisika; Hasan Ibnu Haytsam (Alhazen), al-Farisi (pengarang karya optik impresif), Al-Kindi (Al-Kindus), dan Abdussalam (ilmuan muslim modern yang mendapatkan penghargaan nobel dalam bidang fisika pada tahun 1979)

c. Ilmuan biologi; Ad-Damiri, Al-Jahiz, Ibnu Wafid, dan Abu Khayr.

${ }^{12}$ Ibrahim Kalin dalam Ted Peters, Muzzaffat Iqbal, Syed Nomanul Haq (editor), Tuhan, Alam, Manusia: Perspektif Sain dan Agama (Bnadung: Mizan bekerjasama dengan CRCS-UGM, 2006), hlm. 72.

${ }^{13}$ Ibid., hlm. 34.

${ }^{14}$ Disarikan dari Samsul M. Hady, Peta Pemikiran Pada Masa Renaissans Islam, dalam Luthfi Musthofa dan Helmi Syaifuddin (editor), Intelektual Islam, Melacak. Akar-Akar Integrasi Ilmu dan Agama, LKQS \& UIN Malang; Malang, 2007; Ahmad Barmawi, 118 Tokoh Muslim Genius Dunia, Restu Agung: Jakarta, 2006; dan Hery Sucipto, Ensiklopedi Tokoh Islam dari Abu Bakar Hingga Nasr dan Qardhawi (Bandung: Mizan, 2003), hlm. 25. 
d. Ilmuan kedokteran; Ibnu Masawayh, Abu Qasim AzZahrawi (Abucais), Ibnu Sina (Avicenna), Ibnu Rusyd (Averoes), Ibnu Al-Baythar, dan lain-lain.

e. Ilmu geografi; Ibnu Majid, Haji Khalifa, dan Yaqut AlHamawi.

f. Ilmuan astronomi; Al-Biruni, Al-Battani, Umar Al-Kayyam, dan Tsabiq bin Qurrah.

g. Ilmuan matematika; Al-Hawarizmi (Algorism), Al-kharki, dan Al-Kalasadi (pencipta notasi pecahan modern).

Ian Barbour ${ }^{15}$ berusaha memetakan hubungan ilmu dan agama dalam empat tipologi yaitu konflik, independensi, dialog dan integrasi. John F. Haught ${ }^{16}$ juga melakukan hal yang sama dengan menggunakan istilah yang berbeda yaitu konflik, kontras, kontak dan konfirmasi.

Konflik, Hubungan ini ditandai dengan adanya dua pandangan yang saling berlawanan antara ilmu dan agama dalam melihat satu persoalan. Keduanya sama-sama memiliki argumentasi yang tidak hanya berbeda tetapi saling bertentangan bahkan menafikan satu dengan yang lain. Ian Barbour ${ }^{17}$, seorang fisikawan sekaligus teolog, mencatat bahwa momentum kuat munculnya konflik antara ilmu dan agama terjadi pada masa Abad pertengahan, manakala otoritas gereja menjatuhkan hukuman kepada Galileo Galilei pada tahun 1633 karena mengajukan teori Copernicus bahwa bahwa bumi dan planet-planet berputar mengelilingi matahari (heliosentris) dan menolak teori Ptolemaeus yang didukung oleh otoritas ilmiah Aristoteles dan otoritas kitab suci yang menyakini bahwa bumi sebagai pusat alam semesta (geosentris).

${ }^{15}$ Ian Barbour, Nature, Human Nature, and God (Minneapolis: Fortress Press, 2002), hlm. 47-50.

${ }^{16}$ John F. Haught, Science and Religion: From Conflict to Conversation, terjemahan Fransiskus Borgias, Perjumpaan Sains dan Agama: dari Konflik ke Dialog (Bandung: Mizan 2004), bekerjasama dengan CRCS Yogyakarta dan ICAS Jakarta, hlm. 43.

${ }^{17}$ John F. Haught, Op.Cit., Science and Religion, hlm, 47-50. 
Independensi, Pandangan ini menempatkan ilmu dan agama tidak dalam posisi konflik. Kebenaran ilmu dan agama samasama absah selama berada pada batas ruang lingkup penyelidikan masing-masing. Ilmu dan agama memiliki tolok ukur kebenaran yang berbeda sehingga agama tidak boleh dinilai menggunakan tolok ukur ilmu, demikian pula sebaliknya. Ilmu dan agama tidak perlu saling mencampuri satu dengan yang lain, sehingga tidak ada artinya mempertentangkan keduanya. ${ }^{18}$

Dialog, Pendekatan independensi meskipun merupakan pilihan yang cukup aman, namun dapat menjadikan realitas kehidupan menjadi terbelah. Penerimaan kebenaran antara ilmu dan agama menjadi satu pilihan dikotomis yang membinggungkan karena tidak dapat mengambil kedauanya sekaligus. Adapaun bagi seseorang yang berusaha menerima keduanya akan mengalami split personality, berkepribadian ganda, karena menerima dua macam kebenaan yang saling berseberangan. Menurut Barbour ${ }^{19}$, pendekatan ini membantu tetapi membiarkan segala sesuatu berada pada jalan buntu yang bisa membuat orang putus asa.

Pendekatan dialog memandang bahwa ilmu dan agama tidak dapat disekat dengan kotak-kotak yang sama sekali terpisah, meskipun pendekatan ini menyadari bahwa keduanya berbeda secara logis, linguistik maupun normatif. Bagaimanapun juga, di barat, agama telah memberikan banyak inspirasi bagi berkembangnya ilmu, demikian pula penemuan-penemuan ilmiah juga mempengaruhi teologi. Meskipun keduanya berbeda namun tidak mungkin benar-benaar dipisahkan. ${ }^{20}$

Integrasi. Ada dua makna dalam tipologi ini, pertama bahwa integrasi mengandung makna implisit reintegrasi, yaitu menyatukan kembali ilmu dan agama setelah keduanya terpisah; kedua, integrasi mengandung makna unity, yaitu bahwa ilmu dan agama merupakan kesatuan primodial. Makna yang pertama

${ }^{18}$ Ibid., hlm. 7-9.

${ }^{19}$ Ian Barbour, Religion in an Age Science (Harper \& Row: New York, 1990), hlm. 15 .

${ }^{20}$ Aqom Kuswanjono., Integrasi Ilmu dan Agama, hlm. 59. 
populer di Barat karena kenyataan sejarah menunjukkan keterpisahan itu. Adapun makna yang kedua lebih banyak berkembang di dunia Islam karena secara ontologis diyakini bahwa kebenaran ilmu dan agama adalah satu, perbedaannya pada ruang lingkup pembahasan, yang satu pengkajian dimulai dari pembacaan al-Qur'an, yang satu dimulai dari bacaan alam. Kebenaran keduanya saling mendukung dan tidak saling bertentangan. Kalau pun terjadi pertentangan dipahami sebagai perbedaan interpretasi manusia dalam memahami al-Qur'an ataupun alam, meminjam istilah Immanuel Kant, perbedaan yang terjadi hanya pada kawasan fenomena tidak pada kawasan noumena. Ilmu dan pengetahuan manusia lebih banyak fenomena tersebut. Melalui pendekatan filsafat, seseorang akan dibawa untuk memahami kawasan yang noumenal tersebut.

Tipologi integrasi juga memiliki beberapa model, yaitu pertama, integrasi teologis yang dikemukakan oleh Ian Barbour. ${ }^{21}$ Model ini menempatkan pekembangan pemahaman teologi sejalan dengan perkembangan ilmu. Pemahaman teologi sebagaimana ilmu dapat direkonstruksi secara terus menerus, bahkan atas nama belajar ilmu, dengan tetap memperhatikan ajaran dasarnya, pemahaman teologi dapat berubah. Kedua, agama sebagai konfirmasi ilmu yang dikemukan oleh John F. Haught. ${ }^{22}$ Model ini memposisikan agama sebagai konfirmasi terhadap perkembangan ilmu, tentu yang tidak merusak. Bentuk dari integrasi yang dimaksud sebagai upaya mengakar ilmu beserta asumsi metafisisnya pada pandangan dasar agama tentang realitas. Ketiga, integrasi pengetabuan yang dikemukakan oleh Oliver L. Reiser. ${ }^{23}$ Integrasi yang hendak dibangun dalam humanisme kosmis ini berpijak pada konsep dasar manusia sebagai masyarakat global penghuni planet bumi. Dengan kesadaran kosmis yang dimiliki manusia akan mampu mentransendensikan keragaman

${ }^{21}$ Ian Barbour, Nature, Human Nature, hlm. 82-83.

${ }^{22}$ John F. Haught., Science and Religion, hlm. 28.

${ }^{23}$ Oliver L. Reiser, Cosmic Humanism and World Unity (Pondicherry India: World Union Journal, 19. September 1973), hlm. 2. 
ilmu maupun agama. Keempat, islamisasi ilmu yang dikemukakan oleh Naquib Al-Attas dan Ismail Raji Al-Faruqi. ${ }^{24}$ Islamisasi ilmu dimaksudkan sebagai upaya dewesternisasi ilmu yang telah menyusup dalam seluruh aspek keilmuan. Ilmu harus dibersihkan dari noda sekularisme, dengan meletakkan kembali otoritas wahyu dan intuisi. Kelima, Pengilmuan Islam yang dikemukan oleh Kuntowijoyo. ${ }^{25}$ Model ini membalik konsep Islamisasi ilmu yang merupakan gerakan dari konteks ke teks menjadi gerakan dari teks menuju ke konteks, artinya Islam (teks al-Qur'an dan AsSunnah) dijadikan sebagai paradigma bagi pengembangan ilmu.

\section{Hakikat Integrasi Ilmu dan Agama}

Konsep hakikat integrasi ilmu dan agama yang direfleksi dari filsosof Mullâ Sadrâ dapat dipahami dalam tiga pendekatan:

\section{a. Integrasi Ontologi Ilmu dan Agama}

Ontologi adalah salah satu cabang filsafat yang membicarakan masalah yang ada, baik bersifat fisik maupun non fisik. Ontologi lebih banyak berbicara tentang hakikat tentang yang ada sehingga seringkali disamakan dengan metafisika yaitu ilmu yang membicarakan tentang realitas, kualitas, kesempurnaan, yang ada, yang oleh Aristoteles disebut sebagai filsafat pertama. ${ }^{26}$

Yang ada dapat dibedakan dalam tiga hal, yaitu mustahil ada, mungkin ada dan wajib ada. Yang dimaksud dengan mustahil ada adalah sesuatu yang keberadaannya bersifat mustahil, yang tidak ada dalam realitas kongkret, misalnya kuda terbang. Tidak ada realitas kongkret makhluk ini kecil hanya dalam cerita fiktif atau khayalan semata. Adapun mungkin ada adalah sesuatu yang keberadaannya bersifat mungkin, yaitu mungkin ada mungkin tidak ada. Keberadaan sesuatu yang bersifat mugkin ini sangat

${ }^{24}$ Syekh Muhammad Naquib Al-Attas, Islam dan Sekulerisme (Bandung: Pustaka, 1981), hlm. 20; Ismail Raji' Al-Faruqi, Islamisasi Pengetahuan (Bandung: Pustaka Salaman, 1984), hlm. 92.

25 Kontowijoyo, Islam Sebagai Ilmu: Epistemologi, Metodologi Dan Etika (Yogyakarta: Tiara Wacara, 2007), hlm. 1.

${ }^{26}$ Lorens Bagus, Metafisika (Jakarta: Gramedia Pustaka Utama, 1991), hlm. 19. 
tergantung pada sesuatu yang menjadi penyebab keberadaannya. Misalnya kursi akan ada apabila ada kayu atau besi yang menjadi sebab bahannya (kausa materialis), terhadap sebab bentuk. Sedangkan wajib ada adalah keberadaan sesuatu yang sifatnya wajib. Ia ada tidak karena disebabkan oleh sesuatu yang lain namun justru menjadi penyebab atas keberadaan segala sesuatu. Inilah yang oleh Aristoteles disebut sebagai kausa prima, yang dalam bahasa agama disebut dengan Tuhan. ${ }^{27}$

Secara ontologis, hubungan ilmu dan agama bersifat integratif- interdependensif, artinya eksistensi (keberadaan) ilmu dan agama saling bergantung satu sama lain. tidak ada ilmu tanpa agama dan tidak agama tanpa ilmu. Ilmu dan agama secara mordial berasal dari dan merupakan bagian dari Tuhan, oleh karena ilmu adalah salah satu dari nama Tuhan, sehingga eksistensi (wujud) ilmu dan agama adalah identik dan menyatu dalam eksistensi Tuhan. ${ }^{28}$ Penjelasan ini menegaskan bahwa eksistensi (wujud) ilmu dan agama dalam dirinya sendiri tidak mengalami konflik. Apabila ada konflik sesungguhnya bukan konflik antara ilmu dan agama, melainkan konflik pemahaman ilmuwan dan agamawan.

\section{b. Integrasi Epistemologi Ilmu dan Agama}

Setiap pandangan epistemologi pasti didasari oleh suatu pemahaman ontologi tertentu. Seseorang yang menyakini bahwa hakekat segala sesuatu adalah materi (materialisme), maka bangunan epistemologinya pun akan bercorak materialisme. Paham ini akan mengarahkan setiap penyelidikannya pada apa yang dianggapnya sebagai hakiki, yaitu materi. Paham ini dapat dilihat misalnya pada empirisme, rasionalisme, dan positivisme. Demikian pula bagi seseorang yang secara ontologis menyakini bahwa kenyataan hakiki adalah yang non-materi, mereka juga akan mengarahkan penyelidikannya pada yang non materi, paham ini dapat dilihat misalnya pada intuisionisme.

27 Aqom Kuswanjono, Integrasi Ilmu dan Agama, hlm. 92.

${ }^{28}$ Ibid., hlm. 114-118. 
Contoh yang sederhana dapat dikemukakan bahwa apabila seorang ilmuwan tidak mempercayai adanya jin, setan, atau malaikat, maka ia tidak akan mungkin mengembangkan penyelidikan datau menciptakan suatu disiplin ilmu untuk mengkaji jin, setan dan malaikat. Namun kalau ia mempercayai, tidak mustahil ia akan berusaha mengembangkan penyelidikan itu dan lebih jauh menjadikannya sebagai disiplin ilmu. ${ }^{29}$

Secara epistemologi, hubungan ilmu dan agama bersifat integratif-komplementer, artinya seluruh metode yang diterapkan dalam ilmu dan agama saling melengkapi satu sama lain. dalam pencarian kebenaran ilmu tidak hanya menerima sumber kebenaran dari empiris dan rasio saja, namun juga menerima sumber kebenaran dari intuisi dan wahyu. Kebenaran ilmiah juga tidak hanya melalui usaha/ capaian (acquired knowledge), namun juga melalui pembersihan diri dan pendekatan diri kepada Tuhan sehingga ilmu itu hadir dalam diri manusia (knowledge by presence). Oleh karena itu memiliki makna spiritual, artinya pencapaian ketinggian ilmu akan berkorelasi dengan kedekatannya kepada Tuhan. Ilmu bukan hanya sarana untuk mencapai kebenaran (kecil) namun juga mencapai kepada kenaraan (skala besar). ${ }^{30}$ Bahan filsafat meliputi obyek yang fisik maupun yang metafisik. Salah satu contohnya adlaah untuk memahami hakikat manusia, pedekatan yang dilakukan melalui empirisme, rasionalisme, intuisionisme, dan wahyu, justru akan menghasilkan pemahaman yang komprehensif.

\section{c. Integrasi Aksiologi Ilmu dan Agama}

Aksiologi adalah salah satu cabang filsafat yang membahas masalah nilai, sehingga aksiologi diartikan sebagai filsafat nilai. Beberapa persoalan yang dibahas antara lain adalah: apa sesungguhnya nilai itu, apakah nilai bersifat obyektif atau

${ }^{29}$ Mulyadi Kartanegara, Integrasi Ilmu, Sebuab Rekonstruksi Holistik (Bandung: Mizan dan UIN Jakarta Press, 2005), hlm. 209.

${ }^{30}$ Aqom Kuswanjono, Integrasi Ilmu dan Agama, hlm. 139-141. 
subyektif, apakah fakta mendahului nilai ataukah nilai mendahului fakta.

Sebagai cabang filsafat, aksiologi memiliki ranting yaitu logika yang membicarakan nilai kebenaran, dalam arti kebenaran rasional; etika yang membicarakan nilai kebaikan; dan estetika yang membicarakan nilai keindahan. Dalam persoalan ini sebenarnya ada stu nilai lagi yaitu keilahian yang secara khusus dibicarakan dalam teologi, namun teologi bukanlah ranting aksiologi darena merupakan cara ilmu tersendiri. Oleh karen aksiologi berbicara tentang berbagai tentang hal tentang nilai, maka ada sementara pendapat mengatakan bahwa filsafat tidak lain adalah sksiologi itu sendiri. ${ }^{31}$

Secara aksiologis, hubungan ilmu dan agama bersifat integratif-kualifikatif, artinya seluruh nilai (kebenaran, kabaikan, keindahan dan keilahian) saling mengkualifikasi satu dengan yang lain. nilai kebenaran yang seringkali menjadi tolok ukur utama ilmu, merupakan kebenaran yang baik, yang indah dan yang ilahiah sekaligus. Justifikasi ilmu tidak hanya benar-salah (nilai kebenaran) saja, namun juga termasuk didalamnya baik buruk (nilai kebaikan), indah jelek (nilai keindahan), dan sakral-profan/ halal haram (nilai keilahian). Ilmu tidak bebas nilai, ilmu tidak hanya untuk ilmu tetapi harus disinari oleh nilai tertinggi, yaitu nilai ilahian (ketuhanan). Implikasi atas saling mengkualifikasinya keseluruhan nilai dalam ilmu akan mengarahkan perkembangan ilmu menjadi ilmu yang bermoral. ${ }^{32}$

Integrasi ilmu dan agama memerlukan landasan filosofi yang didalamnya terdiri atas tiga pilar yaitu ontologi, epistemologi, dan aksiologi. Sehingga agama tidak menjadi landasan etis namun lebih luas menjadi landasan filosofis bagi perkembangan ilmu. Dengan demikian outcome yang dihasilkan dari institusi yang menginginkan integrasi ilmu dan agama adalah bukan hanya ilmuwan muslim namun ilmuwan Islam. Ilmuwan muslim yang

\footnotetext{
${ }^{31}$ Ibid., hlm. 141.

${ }^{32}$ Ibid., hlm. 148-149.
} 
dimaksud adalah ilmuan yang beragama Islam yaitu seseorang yang menguasai ilmu dan kuat keimanannya, sedangkan ilmuwan Islam adalah ilmuan yang tidak hanya kuat keimanannya namun yang dapat menjadikan Islam sebagai paradigma bagi pengembangan ilmu.

\section{Simpulan}

Paparan diatas menunjukkan bahwa integrasi ilmu agama dan ilmu umum memerlukan sentuhan ibunya ilmu tak lain lagi adalah landasan filosofi yang didalamnya terdiri atas tiga pilar yaitu ontologi, epistemologi, dan aksiologi. Sehingga agama tidak menjadi landasan etis namun lebih luas menjadi landasan filosofis bagi perkembangan ilmu. Dengan demikian outcome yang dihasilkan dari institusi yang menginginkan integrasi ilmu dan agama adalah bukan hanya ilmuwan muslim namun ilmuwan Islam. Ilmuwan muslim yang dimaksud adalah ilmuan yang beragama Islam yaitu seseorang yang menguasai ilmu dan kuat keimanannya, sedangkan ilmuwan Islam adalah ilmuan yang tidak hanya kuat keimanannya namun yang dapat menjadikan Islam sebagai paradigma bagi pengembangan ilmu.

Secara ontologis, epistemologis dan aksiologis, hubungan integrasi yang holistik antara ilmu dan agama dapat digambarkan sebagai berikut: ${ }^{33}$

${ }^{33}$ Aqom Kuswanjono, Op.Cit., Integrasi Ilmu dan Agama....., Hal. 149-150 
Ontologi Epistemologi $\quad$ Aksiologi

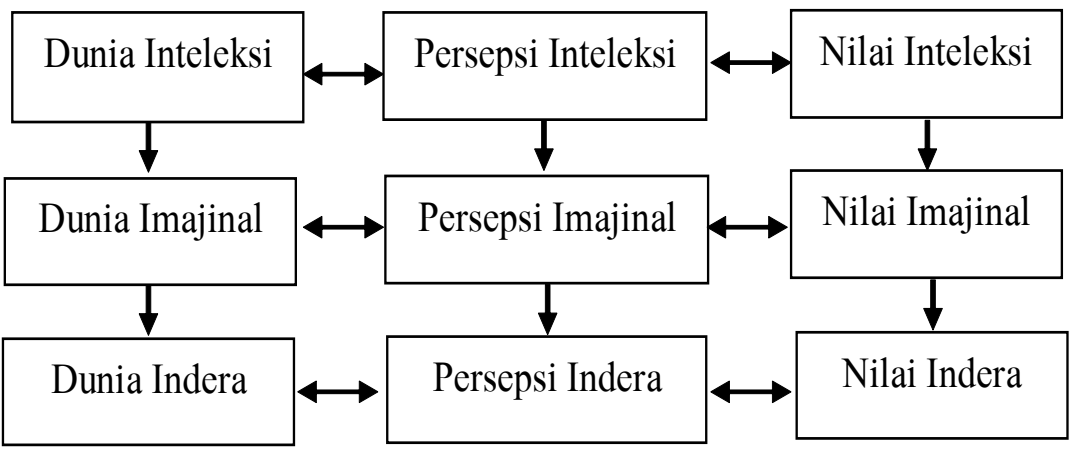

Konsep integrasi holistik ilmu dan agama selain bersifat gradatif (meliputi tingkat inteleksi, imajinasi dan indera), merupakan kesatuan pula antara dunia inteleksi (ontologi), persepsi inteleksi (epistemologi), nilai inteleksi (aksiologi). Secara lebih sederhana bagan tersebut dapat digambarkan sebagai berikut:

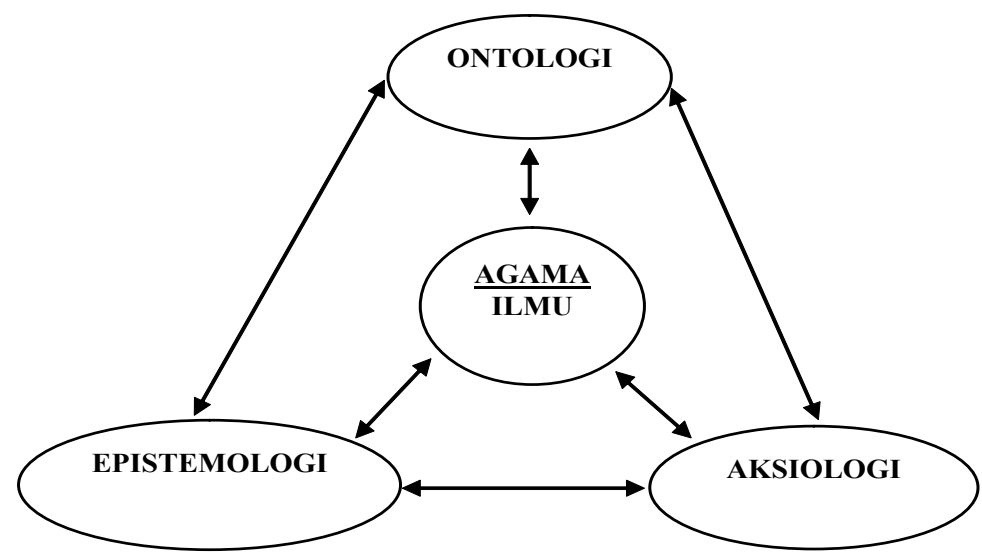

Bagan diatas memberikan gambaran tentang dua hal; pertama, integrasi ilmu dan agama. Kedua, integrasi antara ontologi, epistemologi, dan aksiologi.

Integrasi antara ilmu dan agama. Ilmu dan agama bukan sesuatu yang terpisah dan bukan pula sesuatu yang satu berada diatas yang lain. Pandangan bahwa agama lebih tinggi dari ilmu 
adalah pengaruh dari konsep tentang dikotomi ilmu dan agama. Ilmu dianggap sebagai ciptaan manusia yang memiliki kebenaran relatif yang oleh karenanya memiliki posisi lebih rendah dibanding agama sebagai ciptaan Tuhan yang memiliki kebenaran absolut.

Demikian kesimpulan akhir dari integrasi ilmu dan agama yang dibangun dalam paradigma filsosof Mullâ Sadrâ yaitu integrasi yang interdependentif-komplementer-kualifikatif, yaitu kristitalisasi dari landasan ontologis, epistemologis dan aksiologis atas ilmu. 


\section{DAFTAR PUSTAKA}

Al-Attas, Muhammad Naquib, Islam dan Sekulerisme, Bandung: Pustaka, 1981.

Al-Faruqi, Ismail Raji', Islamisasi Pengetahuan, Bandung: Pustaka Salaman, 1984.

Bagus, Lorens, Metafisika, Jakarta: Gramedia Pustaka Utama. 1991.

Barbour, Ian. Religion in an Age Science, New York: Harper \& Row, 1990.

Nature, Human Nature, and God, Minneapolis: Fortress Press, 2002.

Barmawi, Ahmad, 118 Tokoh Muslim Genius Dunia, Jakarta: Restu Agung, 2006.

Gie, The Liang, Pengantar Filsafat Ilmu, Yogyakarta: Yayasan Studi Ilmu dan Teknologi, 1987.

Hady, Samsul M., Peta Pemikiran Pada Masa Renaissans Islam, dalam Luthfi Musthofa dan Helmi Syaifuddin (editor), Intelektual Islam, Melacak. Akar-Akar Integrasi Ilmu dan Agama, Malang: LKQS \& UIN Malang, 2007.

Haught, John F. Science and Religion: From Conflict to Conversation, terjemahan Fransiskus Borgias. Perjumpaan Sains dan Agama: dari Konflik ke Dialog, Bandung: Mizan bekerjasama dengan CRCS Yogyakarta dan ICAS Jakarta, 2004.

Jammer, Max, Agama Eistein: Teologi dan Fisika, , Yogyakarta: Relief-CRCS, 2004.

Kartanegara, Mulyadi, Integrasi Ilmu, Sebuah Rekonstruksi Holistik, Bandung: Arasy Mizan dan UIN Jakarta Press, 2005.

Kontowijoyo, Islam Sebagai Ilmu: Epistemologi, Metodologi Dan Etika, Yogyakarta: Tiara Wacara, 2007. 
Kuswanjono, Aqom, Integrasi Ilmu dan Agama Perspektif Filsafat Mulla Sadra, Yogyakarta: Badan Penerbitan Filsafat UGM, 2010.

Mehdi Golshani, Issue In Islam and Science, Tehran Iran: IHCN, 1994.

Mohd, Wan, Nor Wan Daud. Tt, The Concept of Knowledge in Islam and Its Implication For Education in Developing Country, terj. Munir, Konsep Pengetahuan dalam Islam, Bandung: Pustaka, 1997.

Mukti Ali, Agama, Universitas dan Pembangunan, Bandung: Badan Penerbit IKIP, 1971.

Nn, 4 Tahun Universitas Islam Negeri (UIN) Malang, Malang: UIN Press, 2009.

Pals, Daniel L, Seven Theories of Religion, terj. Ali Noer Zaman, Yogyakarya: Kalam, 2001.

Peters, Ted, Muzzaffat Iqbal, Syed Nomanul Haq (editor), Tuhan, Alam, Manusia: Perspektif Sain dan Agama, Bandung: Mizan bekerjasama dengan CRCS-UGM, Yogyakarta, 2006.

Reiser, Oliver L, Cosmic Humanism and World Unity, World Union Journal, India: Pondicherry: 19 September 1973.

Saifuddin, Endang Anshari, Imu Filsafat dan Agama, Surabaya: Bina Ilmu, 1987.

Sucipto, Hery, Ensiklopedi Tokoh Islam dari Abu Bakar Hingga Nasr dan Qardhawi, Bandung: Mizan, 2003. 
